\section{UNIWERSYTET \\ SZCZECIŃSKI}

Zeszyty

Naukowe

n r 858
Wspótczesne

Problemy

Ekonomiczne

$n r 11(2015)$

DOI: 10.18276/wpe.2015.11-17

\title{
Ewelina Młodzik*
}

\section{Założenia koncepcji New Public Management}

Słowa kluczowe: New Public Management, zarządzanie publiczne, efektywność i skuteczność w sektorze publicznym

Keywords: New Public Management, public management, efficiency and effectiveness in the public sector

\section{Wprowadzenie}

Kryzysy gospodarcze i polityczne lat osiemdziesiątych i dziewięćdziesiątych XX wieku, słabości nadmiernie rozbudowanego sektora publicznego oraz krytyka tradycyjnego modelu administracji stanowiły główne źródło inspiracji dla poszukiwania bardziej skutecznych i efektywnych form zarządzania państwem.

Poprawa jakości zarządzania miała nastąpić poprzez absorpcję do sektora publicznego mechanizmów rynkowych oraz metod i technik zarządczych szeroko wykorzystywanych w sektorze prywatnym, a także nastawienie administracji na skuteczność działania, ekonomiczną wydajność, jakość oraz zorientowanie na wyniki. Rozpoczęte w tym celu procesy reformowania administracji publicznej określa się mianem Nowego Zarządzania Publicznego (New Public Management).

Celem artykułu jest zaprezentowanie koncepcji New Public Management. W artykule zwrócono uwagę na przesłanki rozwoju, definicje, modele, główne postulaty koncepcji oraz ograniczenia związane z jej implementacją do sektora publicznego.

\footnotetext{
* Magister Ewelina Młodzik jest asystentem na Wydziale Nauk Ekonomicznych i Zarządzania (Katedra Sprawozdawczości Finansowej i Audytu) Uniwersytetu Szczecińskiego. E-mail: ewelina.mlodzik@wneiz.pl.
} 


\section{Przesłanki rozwoju koncepcji New Public Management}

Poszukiwania nowych idei zarządzania koncentrowały się wokół negowania modelu idealnej biurokracji M. Webera i zastępowania go modelem menedżerskiego zarządzania publicznego. Należy jednak zaznaczyć, że model menedżerski nie jest całkowitym zaprzeczeniem tradycyjnego modelu administracji. Zdaniem J. Hausnera ${ }^{1}$,,niektóre zasady i rozwiązania zaproponowane przez niemieckiego socjologa są w tym modelu zachowane, jak na przykład: dobór personelu według kryterium kompetencji, powszechny i ustrukturyzowany system wynagradzania oraz awansu czy też mechanizmy oceny wyników działania osób i zespołów pracowniczych. Zasadnicza różnica tkwi w mechanizmie kontroli, która dotyczy przede wszystkim wyników działania, a nie przestrzegania procedur".

W opinii D. Osborne’a i T. Gaeblera „trudno sobie dzisiaj wyobrazić, ale sto lat temu słowo biurokracja miała znaczenie pozytywne. Oznaczało ono racjonalną, sprawną metodę organizacji, coś, co miało zastąpić arbitralną władzę sprawowaną przez autorytarne reżimy. Biurokracja wniosła do rządzenia ten sam logiczny porządek, co linia produkcyjna do fabryk. Opierając się na hierarchicznej strukturze organów władzy i zarządzania oraz na ich funkcjonalnej specjalizacji, umożliwiała podejmowanie wielkich, kompleksowych zadań"2.

Jak zauważają autorzy, „model biurokratyczny rozwinął się jednak w warunkach zupełnie odmiennych od tych, z jakimi mamy do czynienia dzisiaj. Powstał on w społeczeństwie nieznającym pośpiechu, w czasach, kiedy wszelkie zmiany dokonywały się powoli. Powstał w epoce, w której tylko ci, którzy znajdowali się na szczycie piramidy władzy, mieli dostęp do informacji niezbędnych do podejmowania przemyślanych decyzji. Powstał w społeczeństwie, które utrzymywało się z pracy rąk, nie z pracy umysłów. [...] Dzisiaj wszystko to należy do przeszłości. Żyjemy w epoce informacji, w której prawie każdy ma tak samo szybki dostęp do danych jak przywódcy kraju, mamy gospodarkę opierającą się na nauce, a doskonale wykształceni pracownicy buntują się przeciw rozkazom i domagają się autonomii. Żyjemy w wieku zróżnicowanego rynku towarów i usług, który przyzwyczaił klientów do wysokiej jakości i dużego wyboru produktów. W tym zmienionym otoczeniu powstałe w epoce przemysłowej instytucje biurokratyczne - tak publiczne, jak i prywatne - zupełnie zawodzą. Nowe otoczenie wymaga instytucji elastycznych i łatwo przystosowujących się do zmian"3.

Podobne stanowisko prezentują D. Szcześciło i J. Bełdowski, wskazując, że „,model biurokratyczny był właściwy w warunkach gospodarek przemysłowych pierwszej

J. Hausner, Zarzadzanie publiczne, Scholar, Warszawa 2008, s. 23.

D. Osborne, T. Gaebler, Rzq̨dzić inaczej. Jak duch przedsiębiorczości przenika i przeksztatca administracje publiczna, Media Rodzina of Poznań, Poznań 1992, s. 34.

3 Tamże, s. 37. 
połowy XX wieku. Doszedł jednak do kresu i nie odpowiada już wymogom czasów, których symbolem jest rozwój technologii komunikacyjnych i rozwój gospodarki opartej na wymianie informacji, a nie na produkcji przemysłowej. Realia nowej gospodarki faworyzują techniki zarządzania zapewniające szybkie reagowanie na warunki rynkowe i zapotrzebowanie odbiorców świadczonych usług".

Rozwój administracji publicznej nie polega na odrzucaniu jednego paradygmatu i zastępowaniu go innymi, lecz na stopniowym przechodzeniu od dotychczasowego modelu do nowego z zachowaniem wielu elementów poprzedniego. Należy zatem przyjąć, że wdrożenie postulatów koncepcji Nowego Zarządzania Publicznego nie miało na celu całkowitej modyfikacji zasad obowiązujących w sektorze publicznym, ale wyeliminowanie jego słabości i niedoskonałości.

Implementacja Nowego Zarządzania Publicznego następowała w wielu krajach według różnych scenariuszy. Pierwsze i szczególnie głębokie reformy zostały podjęte w Nowej Zelandii, Australii, Wielkiej Brytanii i Stanach Zjednoczonych. Zainteresowanie Nowym Zarządzaniem Publicznym przeniknęło również do Kanady, Szwecji, Holandii i innych państw europejskich, w tym także do Polski.

\section{Główne postulaty koncepcji New Public Management}

Myślą przewodnią Nowego Zarządzania Publicznego jest przedkładanie w sprawowaniu administracji publicznej sztuki zarządzania nad sztukę administrowania ${ }^{5}$, co trafnie oddają słowa O.E. Huges’a: ,,administrowanie oznacza wypełnianie instrukcji, natomiast zarządzanie to osiąganie rezultatów". Nowe Zarządzanie Publiczne opiera się zatem na zmianie orientacji zarządzania organizacjami publicznymi polegającej na zaprzestaniu stosowania podejścia stawiającego na piedestale procedury i zasady postępowania związane $\mathrm{z}$ dokonywaniem wydatków, a wdrożeniu reguł opartych na analizie osiąganych wyników związanych z ponoszonymi wydatkami, przyjęciu orientacji strategicznej oraz wprowadzeniu mechanizmu rynkowego do procesu świadczenia usług publicznych ${ }^{7}$. Nowe Zarządzanie Publiczne zwiększa nacisk na jakość dostarczanych usług publicznych zorientowanych na potrzeby i oczekiwania obywatela, który jest traktowany jak ,klient administracji”.

4 D. Szcześciło, J. Bełdowski, $W$ stronę nowego zarzqdzania publicznego, http://nawokandzie.ms.gov. $\mathrm{pl} /$ numer-4/opinie-4/w-strone-nowego-zarzadzania-publicznego.html (6.09.2014).

5 J. Hausner, dz. cyt., s. 39.

6 O.E. Huges, Public Management and Administration. An Introduction, The Macmillan Press Ltd., London 1994, s. 39.

7 A. Zalewski, Teoria i praktyka nowego zarzadzania publicznego, w: W stronę teorii i praktyki finansów, red. M. Ostaszewski, M. Zaleska, Wydawnictwo Szkoły Głównej Handlowej, Warszawa 2006, s. 74. 
Zdaniem A. Zalewskiego „Nowe Zarządzanie Publiczne wprowadza podejście menedżerskie do zarządzania sektorem publicznych. Nowość tego modelu zarządzania polega na adaptacji metod $\mathrm{i}$ technik zarządzania stosowanych w sektorze prywatnym do warunków zarządzania organizacjami publicznymi. Chodzi zwłaszcza o nastawienie tych organizacji na osiąganie wyników, decentralizację zarządzania nimi, przejęcie przez nie perspektywy strategicznej oraz wykorzystanie mechanizmów rynkowych. Ten model zarządzania ma zapewnić gospodarność, efektywność i skuteczność organizacji publicznych".

Skuteczność i efektywność są ściśle ze sobą powiązane, ponieważ decydują o sprawności. Powszechnie skuteczność odnosi się do stopnia, w jakim osiągnięte zostały założone cele zadania. Z kolei efektywność dotyczy stopnia osiągnięcia założonych celów przy minimalnych kosztach lub maksymalizacji stopnia osiągnięcia celu przy założonych kosztach ${ }^{9}$.

Efektywność w Nowym Zarządzaniu Publicznym rozumiana jest przede wszystkim jako zapewnienie obywatelom dostępu do usług możliwe najwyższej jakości przy jednoczesnym relatywnie niskim obciążeniu budżetu państwa kosztem ich świadczenia. Należy dodać, że w omawianej koncepcji skuteczność działań danej jednostki nie jest uzależniona od poziomu jej wydatków czy wysokości budżetu, ale od tego, co udało się dzięki tym wydatkom osiągnąć. Uwagę skoncentrowano zatem na efektach ${ }^{10}$.

Z punktu widzenia poprawy skuteczności i efektywności funkcjonowania administracji publicznej istotne jest określenie celów ponoszenia wydatków publicznych przypisanych do zadań i podzadań oraz ich mierników ${ }^{11}$.

Z kolei H. Krynicka przedstawia istotę i cele omawianej koncepcji następująco: „Nowe Zarządzanie Publiczne kładzie nacisk na właściwe wyznaczanie celów i monitorowanie wyników, zarządzanie finansami (efektywność), wyznaczanie standardów usług, korzystanie z rozwiązań benchmarkingowych (możliwość dokonywania porównań na próbie sprawdzonych, dobrych rozwiązań) oraz nowoczesnego zarządzania zasobami ludzkimi”' ${ }^{2}$ I dodaje autorka: „,celem administracji w duchu Nowego Zarządzania Publicznego jest uzyskanie rezultatów oraz kontrola i odpowiedzialność za wyniki, sku-

\footnotetext{
8 A. Zalewski, Reformy sektora publicznego w duchu nowego zarzadzania publicznego, w: Nowe zarzqdzanie publiczne w polskim samorzadzie terytorialnym, red. A. Zalewski, Wydawnictwo Szkoły Głównej Handlowej, Warszawa 2005, s. 66.

9 T. Lubińska, T. Strąk, A. Lozano-Platonoff, M. Będzieszak, M. Godek, Budżet zadaniowy w Polsceistota, struktura, metodyka, w: Budzet zadaniowy w Polsce. Reorientacja z wydatkowania na zarzadzanie pieniędzmi publicznym, red. T. Lubińska, Difin, Warszawa 2007, s. 56.

10 M. Ochnio, Nowe Zarzadzanie Publiczne (New Public Management) - podstawowe cechy modelu. Jego zastosowanie w Polsce, Stowarzyszenie Instytut Zmian, Warszawa 2012, http://iz.org.pl/wp-content/ uploads/2012/09/New_Public_Management_Michal_Ochnio_Instytut_Zmian.pdf, s. 7 (6.09.2014).

11 T. Lubińska, T. Strąk, A. Lozano-Platonoff, M. Będzieszak, M. Godek, dz. cyt., s. 57.

12 H. Krynicka, Koncepcja nowego zarzqdzania w sektorze publicznym (New Public Management), „Studia Lubuskie PWSZ w Sulechowie” 2006, nr 2, s. 195.
} 
teczne działanie wymaga połączenia wysiłków sektora publicznego, prywatnego i pozarządowego na rzecz rozwiązywania problemów"13.

W wyniku przeglądu zasobów literatury poświęconych Nowemu Zarządzaniu Publicznemu można wskazać na następujące cechy charakterystyczne tej koncepcji ${ }^{14}$ :

a) wprowadzenie profesjonalnego zarządzania w sektorze publicznym opartego na wykorzystaniu wiedzy i umiejętności wysoko wykwalifikowanych menedżerów;

b) opracowanie i wykorzystywanie jasno sprecyzowanych standardów i mierników działalności oraz realizacji zadań;

c) wykorzystanie narzędzi kontrolnych, szczególnie w odniesieniu do standardów i mierników działalności oraz realizacji zadań;

d) nastawienie na dezagregację i decentralizację jednostek sektora publicznego;

e) wprowadzenie rzeczywistej konkurencji do jednostek sektora finansów publicznych;

f) wprowadzenie i efektywne adaptowanie technik oraz metod zarządzania stosowanych w sektorze prywatnym;

g) nacisk na dyscyplinę i wykorzystanie zasobów, w tym finansowych.

Rozważania nad istotą Nowego Zarządzania Publicznego nie były poświęcone tylko i wyłącznie próbie usystematyzowania jego definicji. Uwagę skoncentrowano również na badaniach mających na celu wyodrębnienie głównych odmian tego kierunku reform administracji publicznej. Najbardziej znanym przykładem są cztery modele Nowego Zarządzania Publicznego, których twórcami są E. Ferlie, L. Ashburner, L. Fitzgerald oraz A. Pettigrew:

- model NPM 1 - zwiększanie efektywności,

- model NPM 2 - ograniczenie rozmiarów organizacji i decentralizacji zarządzania,

- model NPM 3 - w poszukiwaniu doskonałości,

- model NPM 4 - orientacja na usługi publiczne.

Podstawowe cechy charakteryzujące poszczególne modele zaprezentowano w tabeli 1.

13 Tamże, s. 197.

14 Ch. Hood, A Public Management for All Season?, „Public Administration” 1991, vol. 69 (1), s. 4-5; M. Poniatowicz, J.M. Salachna, D. Perło, Efektywne zarzqdzanie dtugiem w jednostce samorzadu terytorialnego, Wolters Kluwer, Warszawa 2010, s. 55-59; E. Kolthoff, L. Huberts, H. Van den Heuvel, The Ethics of New Public Management: Is Integrity at Stake?, „Public Administration Quarterly” 2007, s. 400-402. 
Tabela 1. Charakterystyka modeli Nowego Zarządzania Publicznego

\begin{tabular}{|c|c|}
\hline Model & Podstawowe cechy modelu \\
\hline $\begin{array}{l}\text { Model NPM } 1 . \\
\text { Zwiększanie } \\
\text { efektywności }\end{array}$ & $\begin{array}{l}\text { Wzrost znaczenia kontroli finansowej. } \\
\text { Maksymalizacja efektów przy ograniczaniu kosztów. } \\
\text { Ustalanie przejrzystych celów działania i monitorowanie wyników. } \\
\text { Rozwój audytu finansowego i merytorycznego. } \\
\text { Wyznaczanie standardów usług i korzystanie z technik benchmarkingu (możliwość dokonywania } \\
\text { porównań na bazie najlepszych praktyk). } \\
\text { Upowszechnianie wykorzystania kwestionariuszy jako narzędzia oceny działalności. } \\
\text { Eksponowanie odpowiedzialności dostawców usług wobec odbiorców. } \\
\text { Zwiększanie orientacji na rynek oraz na klienta. } \\
\text { Wdrażanie nowych wzorów dobrego zarządzania (corporate governance). } \\
\text { Ograniczanie roli organów przedstawicielskich, zwiększenie roli kadry kierowniczej. } \\
\text { Rozliczanie kadry kierowniczej z wyników jej pracy. } \\
\text { Przesuwanie ośrodka władzy w kierunku komórek organizacyjnych podejmujących decyzje } \\
\text { strategiczne. }\end{array}$ \\
\hline $\begin{array}{l}\text { Model NPM } 2 . \\
\text { Ograniczenie } \\
\text { rozmiarów } \\
\text { organizacji } \\
\text { i decentralizacji } \\
\text { zarządzania }\end{array}$ & $\begin{array}{l}\text { Rozwój quasi-rynków usług publicznych. } \\
\text { Zwiększenie roli kontraktowania. } \\
\text { Ograniczanie roli zarządzania hierarchicznego na rzecz zarządzania przez kontrakty. } \\
\text { Zmniejszanie rozmiarów sektora publicznego, spłaszczanie struktur organizacyjnych. } \\
\text { Wzrost znaczenia pracy zespołowej. } \\
\text { Koncentracja na „zarządzaniu poprzez wpływ”. } \\
\text { Odchodzenie od dostarczania usług zestandaryzowanych w kierunku form charakteryzujących się } \\
\text { różnorodnością i elastycznością. }\end{array}$ \\
\hline $\begin{array}{l}\text { Model NPM } 3 . \\
\text { W poszukiwaniu } \\
\text { doskonałości }\end{array}$ & $\begin{array}{l}\text { Radykalna decentralizacja i ocena poprzez uzyskiwane wyniki. } \\
\text { Nacisk na rozwój organizacyjny oraz uczenie się organizacji. } \\
\text { Pojmowanie kultury organizacyjnej jako nośnika procesów zmian. } \\
\text { Intensywne programy szkoleń dla menedżerów. } \\
\text { Nacisk na charyzmatyczne sposoby zarządzania. } \\
\text { Ustalanie misji organizacji oraz wizerunku jej pracownika. } \\
\text { Określanie wizji rozwoju przez liderów organizacji. } \\
\text { Sporządzanie strategii komunikacji społecznej. }\end{array}$ \\
\hline $\begin{array}{l}\text { Model NPM } 4 . \\
\text { Orientacja na usługi } \\
\text { publiczne }\end{array}$ & $\begin{array}{l}\text { Osiągnięcie doskonałości w procesie świadczenia usług publicznych. } \\
\text { Wdrażanie zarządzania przez jakość. } \\
\text { Analiza i uwzględnianie w zarządzaniu opinii usługobiorców. } \\
\text { Przesunięcie władzy z organów mianowanych na wybieralne. } \\
\text { Skoncentrowanie uwagi na rozwoju wiedzy o usługach publicznych wśród obywateli na przykład } \\
\text { poprzez dokonywanie oceny potrzeb społecznych, organizację zadań na rzecz społeczności. } \\
\text { Wdrażanie mechanizmów partycypacji publicznej w zarządzaniu usługami. }\end{array}$ \\
\hline
\end{tabular}

Żródło: opracowanie własne na podstawie: E. Ferlie, L. Ashburner, L. Fitzgerald, A. Pettigrew, The New Public Management in Action, Oxford University Press, Oxford 1996, s. 11-15, za: M. Zawicki, Nowe zarządzanie publiczne, PWE, Warszawa 2011, s. 45-48. 
Nowe Zarządzanie Publiczne obejmuje prace badawcze i rozwojowe mające na celu adaptację do sektora publicznego idei, metod, technik i rozwiązań instytucjonalnych stosowanych w sektorze prywatnym. Pokazuje, w jaki sposób poprzez zastosowanie odpowiednich instrumentów zwiększyć efektywność funkcjonowania administracji publicznej. Misją Nowego Zarządzania Publicznego jest zwiększenie przede wszystkim skuteczności i efektywności, a tym samym sprawności sektora publicznego ${ }^{15}$.

W stosunku do przedstawionych założeń Nowego Zarządzania Publicznego zgłaszane są jednak uwagi krytyczne. Przeciwnicy tej koncepcji wskazują na ograniczone możliwości implementacji modelu nowego zarządzania do sektora publicznego. Dla ich potwierdzenia przywołuje się między innymi następujące argumenty ${ }^{16}$ :

a) Nowe Zarządzanie Publiczne wykorzystuje rozwiązania rynkowe do zaspakajania potrzeb społecznych, w których rynek jako mechanizm alokacji zasobów zawodzi;

b) rynki tworzone w sektorze publicznym nie są rynkami wolnej konkurencji, lecz rynkami konkurencji organizowanej przez różne władze publiczne;

c) w koncepcji nie uznaje się, że siły rynkowe nie są wystarczające do osiągnięcia zadowolenia konsumentów, na przykład społeczne i ekologiczne skutki produkcji wobec kupujących i zatrudnionych;

d) Nowe Zarządzanie Publiczne nie rozpoznaje różnicy między klientem-konsumentem, który finansuje zapewnienie dóbr i usług, a klientem, czyli odbiorcą, który potrzebuje dóbr i usług.

J. Supernat zwraca uwagę na kolejny ważny problem do rozwiązania, którym jest kwestia zapewnienia odpowiedzialności funkcjonariuszy administracji publicznej działających w warunkach decentralizacji i deregulacji oraz obdarzonych zaufaniem społeczeństwa. Na przykład oszczędne gospodarowanie zasobami może zdaniem autora nie być dowodem odpowiedzialności, lecz wręcz przeciwnie - nieodpowiedzialności wyrażającej się w niezrealizowaniu ustalonych celów ${ }^{17}$.

\section{Podsumowanie}

Wiele lat temu J. Madison stwierdził, że ,gdyby ludzie byli aniołami, żaden rząd czy administracja nie byłyby konieczne. Gdyby aniołowie mieli rządzić ludźmi, ani wewnętrzna, ani zewnętrzna kontrola nie byłaby konieczna. Tworząc jednak rząd, w którym

15 B. Bobińska, Funkcjonowanie sektora publicznego jako organizacji „otwartych na klienta”, Zeszyty Naukowe Zachodniopomorskiej Szkoły Biznesu „Firma i Rynek” 2012, nr 1, s. 68.

16 H. Krynicka, dz. cyt., s. 202.

17 J. Supernat, Administracja publiczna w świetle koncepcji New Public Management, http://www.supernat.pl/wyklady/plk/i_3_2_Administracja_publiczna_w_swietle_koncepcji_New_Public_Management.pdf (6.09.2014). 
ludzie będą administrowali ludźmi, stajemy wobec wielkiej trudności: najpierw należy umożliwić rządowi kontrolowanie rządzonych, następnie należy zobowiązać rząd, aby kontrolował się sam"18. Jeżeli pogląd na naturę człowieka w wersji Madisona jest słuszny, to niewątpliwie od nowego zarządzania publicznego należy oczekiwać gwarancji, że bardziej samodzielni funkcjonariusze zderegulowanej administracji publicznej będą dobrymi ludźmi, którzy sumiennie wykonują powierzone im obowiązki ${ }^{19}$.

Uwagi krytyczne wobec Nowego Zarządzania Publicznego zaowocowały pojawieniem się kolejnej koncepcji zarządzania administracją publiczną, którą określa się mianem rządzenia publicznego lub dobrym rządzeniem (good governance). Realizacja tej koncepcji przejawia się w podejmowaniu decyzji i działań charakteryzujących się angażowaniem wszystkich zainteresowanych stron, praworządnością, przejrzystością, odpowiadaniem na potrzeby społeczne, dążeniem do konsensusu, uwzględnianiem głosów mniejszości, efektywnością, jak również szeroko rozumianą odpowiedzialnością wobec społeczeństwa.

\section{Literatura}

Bobińska B., Funkcjonowanie sektora publicznego jako organizacji „otwartych na klienta”, Zeszyty Naukowe Zachodniopomorskiej Szkoły Biznesu „Firma i Rynek” 2012, nr 1.

Ferlie E., Ashburner L., Fitzgerald L., Pettigrew A., The New Public Management in Action, Oxford University Press, Oxford 1996.

Hausner J., Zarzqdzanie publiczne, Scholar, Warszawa 2008.

Hood Ch., A Public Management for All Season?, „Public Administration” 1991, vol. 69 (1).

Huges O.E., Public Management and Administration. An Introduction, The Macmillan Press Ltd., London 1994.

Kolthoff E., Huberts L., Heuvel Van den H., The Ethics of New Public Management: Is Integrity at Stake?, „Public Administration Quarterly” 2007, vol. 30 (4).

Krynicka H., Koncepcja nowego zarzqdzania w sektorze publicznym (New Public Management), „Studia Lubuskie PWSZ w Sulechowie” 2006, nr 2.

Lubińska T., Strąk T., Lozano-Platonoff A., Będzieszak M., Godek M., Budżet zadaniowy $w$ Polsce - istota, struktura, metodyka, w: Budzet zadaniowy w Polsce. Reorientacja z wydatkowania na zarzqdzanie pieniędzmi publicznym, red. T. Lubińska, Difin, Warszawa 2007.

Ochnio M., Nowe Zarzqdzanie Publiczne (New Public Management) - podstawowe cechy modelu. Jego zastosowanie w Polsce, Stowarzyszenie Instytut Zmian, Warszawa 2012, http://iz.org.pl/wp-content/uploads/2012/09/New_Public_Management_Michal_Ochnio_ Instytut_Zmian.pdf.

Osborne D., Gaebler T., Rzqdzić inaczej. Jak duch przedsiębiorczości przenika i przekształca administracje publiczna, Media Rodzina of Poznań, Poznań 1992.

18 D.H. Rosenbloom, R.S. Kravchuk, Public Administration. Understanding Management, Politics, and Law in the Public Sector, McGraw-Hill, New York 2002, s. 182.

19 J. Supernat, dz. cyt. 
Poniatowicz M., Salachna J.M., Perło D., Efektywne zarzqdzanie dlugiem w jednostce samorzqdu terytorialnego, Wolters Kluwer, Warszawa 2010.

Rosenbloom D.H., Kravchuk R.S., Public Administration. Understanding Management, Politics, and Law in the Public Sector, McGraw-Hill, New York 2002.

Supernat J., Administracja publiczna w świetle koncepcji New Public Management, http://www. supernat.pl/wyklady/plk/i_3_2_Administracja_publiczna_w_swietle_koncepcji_New_ Public_Management.pdf.

Szcześciło D., Bełdowski J., W stronę nowego zarzqdzania publicznego, http://nawokandzie. ms.gov.pl/numer-4/opinie-4/w-strone-nowego-zarzadzania-publicznego.html.

Zalewski A., Reformy sektora publicznego w duchu nowego zarzqdzania publicznego, w: Nowe zarzqdzanie publiczne $w$ polskim samorzqdzie terytorialnym, red. A. Zalewski, Wydawnictwo Szkoły Głównej Handlowej, Warszawa 2005.

Zalewski A., Teoria i praktyka nowego zarzadzania publicznego, w: W strone teorii i praktyki finansów, red. M. Ostaszewski, M. Zaleska, Wydawnictwo Szkoły Głównej Handlowej, Warszawa 2006.

Zawicki M., Nowe zarzqdzanie publiczne, PWE, Warszawa 2011.

\section{Streszczenie}

Cel - Celem artykułu jest zaprezentowanie koncepcji New Public Management.

Metodologia badania - W artykule dokonano przeglądu źródeł literaturowych podejmujących problematykę Nowego Zarządzania Publicznego.

Wynik - W wyniku przeglądu dostępnej literatury przedmiotu wskazano na przesłanki rozwoju, główne postulaty oraz odmiany koncepcji New Public Management.

Oryginalność/Wartość - Przedstawiona w artykule charakterystyka koncepcji Nowego Zarządzania Publicznego stanowi usystematyzowanie wiedzy w zakresie omawianego problemu.

\section{Assumptions of the New Public Management concept}

Purpose - The purpose of this article is to present the New Public Management concept.

Design/methodology/approach - This article reviews literature sources that take up the New Public Management issues.

Findings - Following a review of the available literature on the subject in the conditions of development were indicated and variations of the main demands of the concept of the New Public Management.

Originality/value - The characteristics of the New Public Management presented in the article is the systematization of knowledge in the field of the problem. 